\title{
Autoimmune thrombotic thrombocytopenic purpura (TTP) associated with COVID-19
}

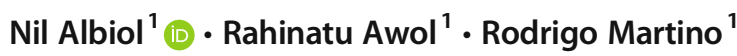 \\ Received: 4 May 2020 / Accepted: 17 May 2020 / Published online: 28 May 2020 \\ (C) Springer-Verlag GmbH Germany, part of Springer Nature 2020
}

Dear Editor:

A 57-year-old woman with a history of hypertension and breast cancer in complete remission was seen in lateMarch 2020 at the emergency ward in a private clinic with dry cough, anosmia, and dysgeusia. Physical examination found a low grade fever $\left(37.8^{\circ} \mathrm{C}\right)$ but was otherwise normal. A thoracic computerized tomography was normal, and a single nasopharyngeal swab (NPS) was reported as negative for severe acute respiratory syndrome coronavirus 2 (SARS$\mathrm{CoV}-2$ ) by a polymerase chain reaction (PCR)-based test. A complete blood work-up was normal except for mild lymphopenia (Day 1 on Table 1).

Because of the pandemic state of SARS-CoV-2 and associated symptoms [1], the treating physicians considered the patient to have coronavirus disease 2019 (COVID-19) but with a false-negative result of the PCR NPS test. The patient was treated with lopinavir/ritonavir, hydroxychloroquine, and azithromycin. On the fifth day of treatment (Day 6 on Table 1) routine blood tests showed severe thrombocytopenia, moderate anemia with a normal reticulocyte count, and high serum lactate dehydrogenase (LDH) and bilirubin (Table 1). Treatment with methylprednisolone $1 \mathrm{mg} / \mathrm{kg} /$ $24 \mathrm{~h}$ and intravenous immunoglobulin was added, but after no improvement in laboratory findings (Day 8 on Table 1), the patient was transferred to our institution for further management.

After initial clinical and laboratory work-up at our institution (Day 9 on Table 1), a diagnosis of autoimmune thrombotic thrombocytopenic purpura (TTP) was rapidly established, based on the presence of microangiopathic hemolytic anemia, severe thrombocytopenia, and very low activity (2\%) of ADAMTS-13 (a disintegrin and metalloproteinase

Nil Albiol

nalbiol@santpau.cat

1 Hematology Department, Hospital de la Santa Creu i Sant Pau, Carrer del Mas Casanovas, 90, 08041 Barcelona, Spain with a thrombospondin type 1 motif, member 13) in combination with the presence of an ADAMTS-13 inhibitor, which is an autoantibody to ADAMTS-13 [2,3].

A NPS sample was retested in our center on admission and was negative for SARS-CoV-2, but serological tests were positive for SARS-CoV-2 IgG, thus confirming the past COVID-19 [4].

Treatment with plasma infusion on admission led to a rapid rise in the patient's platelet count (Day 10 on Table 1). After placement of a central venous catheter, therapeutic plasma exchange was begun, with a favorable clinical and laboratory course over the next week (Day 17 on Table 1).

We present a case of acquired autoimmune TTP whose onset occurred immediately after COVID-19, since the patient was admitted for this latter infection with normal laboratory values.

Of course, this could be a mere coincidence rather than a causal relationship, owing to the very high incidence of SARS-CoV-2 infection [5].

As with other hematological disorders, the COVID-19 pandemic may change the way in which the approach to and management of patients may vary from the standard of care, as highlighted by the American Society of Hematology COVID-19 Resources Center (specific information on TTP can be found at https://www.hematology.org/covid-19/ covid-19-and-ttp).

\section{Compliance with ethical standards}

Conflict of interest The authors declare that they have no conflict of interest.

Ethical approval All procedures performed in studies involving human participants were in accordance with the ethical standards of the institutional and/or national research committee and with the 1964 Helsinki declaration and its later amendments or comparable ethical standards.

Informed consent Informed consent was obtained from all individual participants included in the study. 
Table 1 Evolution of laboratory findings from the day of onset until end of plasma exchange therapy

\begin{tabular}{|c|c|c|c|c|c|c|}
\hline Laboratory test & Day 1 & Day 6 & Day 8 & $\begin{array}{l}\text { Day } 9 \\
\text { (before plasma } \\
\text { infusion) }\end{array}$ & $\begin{array}{l}\text { Day } 10 \\
\text { (after plasma } \\
\text { infusion) }\end{array}$ & $\begin{array}{l}\text { Day } 17 \\
\text { (after } 7 \text { days of plasma } \\
\text { exchange) }\end{array}$ \\
\hline $\mathrm{Hb}(\mathrm{g} / \mathrm{L})(\mathrm{NV} 120-150)$ & 130 & 99 & 83 & 69 & 64 & 97 \\
\hline Platelets $(\times 10 \mathrm{E} 9 / \mathrm{L})(\mathrm{NV} 140-350)$ & 191 & 22 & 23 & 13 & 86 & 220 \\
\hline $\begin{array}{l}\text { Leukocyte count }(\times 10 \mathrm{E} 9 / \mathrm{L}) \\
\quad(\mathrm{NV} 3.80-11.00)\end{array}$ & 4.78 & 5.31 & 17.40 & 20.33 & 12.35 & 9.03 \\
\hline $\begin{array}{l}\text { Lymphocyte count }(\times 10 \mathrm{E} 9 / \mathrm{L}(\%)) \\
\quad(\mathrm{NV} 1.00-4.00)\end{array}$ & $\begin{array}{l}0.57 \\
\quad(12)\end{array}$ & $\begin{array}{l}1.61 \\
\quad(30.3)\end{array}$ & $\begin{array}{r}1.04 \\
(6)\end{array}$ & $3.05(15)$ & $2.45(19.8)$ & $2.17(24)$ \\
\hline $\begin{array}{l}\text { Reticulocyte count }(\times 10 \mathrm{E} 9 / \mathrm{L}(\%)) \\
\quad(\mathrm{NV} 20-100(0.5-2))\end{array}$ & - & - & $69(-)$ & $69.8(3.05)$ & $155.4(7.73)$ & $130.9(4.35)$ \\
\hline Schistocyte count $(\%)(\mathrm{NV}<0.5)$ & - & - & - & 6 & 10 & - \\
\hline Creatinine (mg/L) (NV 0.6-1.2) & 0.80 & 0.80 & 0.68 & 0.72 & 0.68 & 0.61 \\
\hline LDH (U/L) (NV 125-243) & 267 & 1451 & 2315 & 1594 & 950 & 218 \\
\hline $\begin{array}{l}\text { Indirect bilirubin }(\mathrm{mg} / \mathrm{dL})(\mathrm{NV} \\
0.3-1.0)\end{array}$ & - & 1.95 & 1.46 & 0.86 & - & - \\
\hline $\mathrm{CRP}(\mathrm{mg} / \mathrm{L})(\mathrm{NV}<5.0)$ & 43 & 39.80 & 11.60 & 5.8 & 6.6 & $<1.0$ \\
\hline ADAMTS-13 (\%) (NV > 70\%) & - & - & - & 2 & 1.91 & 89 \\
\hline $\begin{array}{l}\text { ADAMTS- } 13 \text { inhibitor } \\
\text { (NV negative or }<0.4 \text { Bethesda } \\
\text { units) }\end{array}$ & - & - & - & $\begin{array}{l}\text { Positive } \\
\text { (5.2 Bethesda units) }\end{array}$ & - & $\begin{array}{l}\text { Positive } \\
\qquad(2.5 \text { Bethesda units })\end{array}$ \\
\hline
\end{tabular}

- refers to non-available tests

$N V$ normal values, $C R P$ C-reactive protein

Consent for publication Consent for publication was obtained from all of the authors.

\section{References}

1. Gane SB, Kelly C, Hopkins C (2020) Isolated sudden onset anosmia in COVID-19 infection. A novel syndrome? Rhinology. https://doi. org/10.4193/Rhin20.114

2. Page EE, Kremer Hovinga JA, Terrell DR, Vesely SK, George JN (2017) Thrombotic thrombocytopenic purpura: diagnostic criteria, clinical features, and long-term outcomes from 1995 through 2015. Blood Adv 1(10):590-600. https://doi.org/10.1182/bloodadvances. 2017005124
3. Coppo P, Schwarzinger M, Buffet $M$ et al (2010) Predictive features of severe acquired ADAMTS13 deficiency in idiopathic thrombotic microangiopathies: the French TMA reference center experience. PLoS One 5(4). https://doi.org/10.1371/journal.pone.0010208

4. Zhao J, Yuan Q, Wang H, Liu W, Liao X, Su Y, Wang X, Yuan J, Li T, Li J, Qian S, Hong C, Wang F, Liu Y, Wang Z, He Q, Li Z, He B, Zhang T, Fu Y, Ge S, Liu L, Zhang J, Xia N, Zhang Z (2020) Antibody responses to SARS-CoV-2 in patients of novel coronavirus disease 2019. Clin Infect Dis. https://doi.org/10.1093/cid/ciaa344

5. WHO. Situation Report-91 HIGHLIGHTS.; 2020.

Publisher's note Springer Nature remains neutral with regard to jurisdictional claims in published maps and institutional affiliations. 